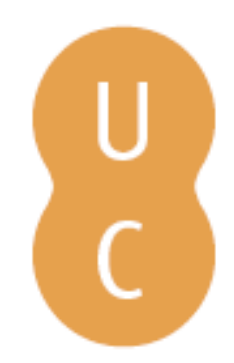

\title{
pompalina
}

\section{Cinco tópicos sobre a crise política global numa era de compressão}

\author{
Autor(es): Rocha-Cunha, Silvério da \\ Publicado por: Imprensa da Universidade de Coimbra \\ URL \\ persistente: \\ URI:http://hdl.handle.net/10316.2/47426 \\ DOI: \\ DOI:https://doi.org/10.14195/978-989-26-1524-0_2
}

Accessed : $\quad$ 26-Apr-2023 11:13:08

A navegação consulta e descarregamento dos títulos inseridos nas Bibliotecas Digitais UC Digitalis, UC Pombalina e UC Impactum, pressupõem a aceitação plena e sem reservas dos Termos e Condições de Uso destas Bibliotecas Digitais, disponíveis em https://digitalis.uc.pt/pt-pt/termos.

Conforme exposto nos referidos Termos e Condições de Uso, o descarregamento de títulos de acesso restrito requer uma licença válida de autorização devendo o utilizador aceder ao(s) documento(s) a partir de um endereço de IP da instituição detentora da supramencionada licença.

Ao utilizador é apenas permitido o descarregamento para uso pessoal, pelo que o emprego do(s) título(s) descarregado(s) para outro fim, designadamente comercial, carece de autorização do respetivo autor ou editor da obra.

Na medida em que todas as obras da UC Digitalis se encontram protegidas pelo Código do Direito de Autor e Direitos Conexos e demais legislação aplicável, toda a cópia, parcial ou total, deste documento, nos casos em que é legalmente admitida, deverá conter ou fazer-se acompanhar por este aviso.

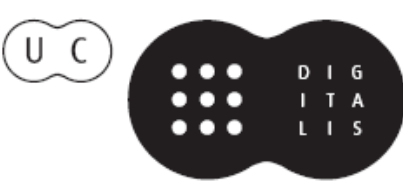


JOSÉ MANUEL PUREZA JOSÉ JUSTE RUIZ (COORDS.)
IMPRENSA DA

UNIVERSIDADE

DE COIMBRA

COIMBRA

UNIVERSITY

PRESS
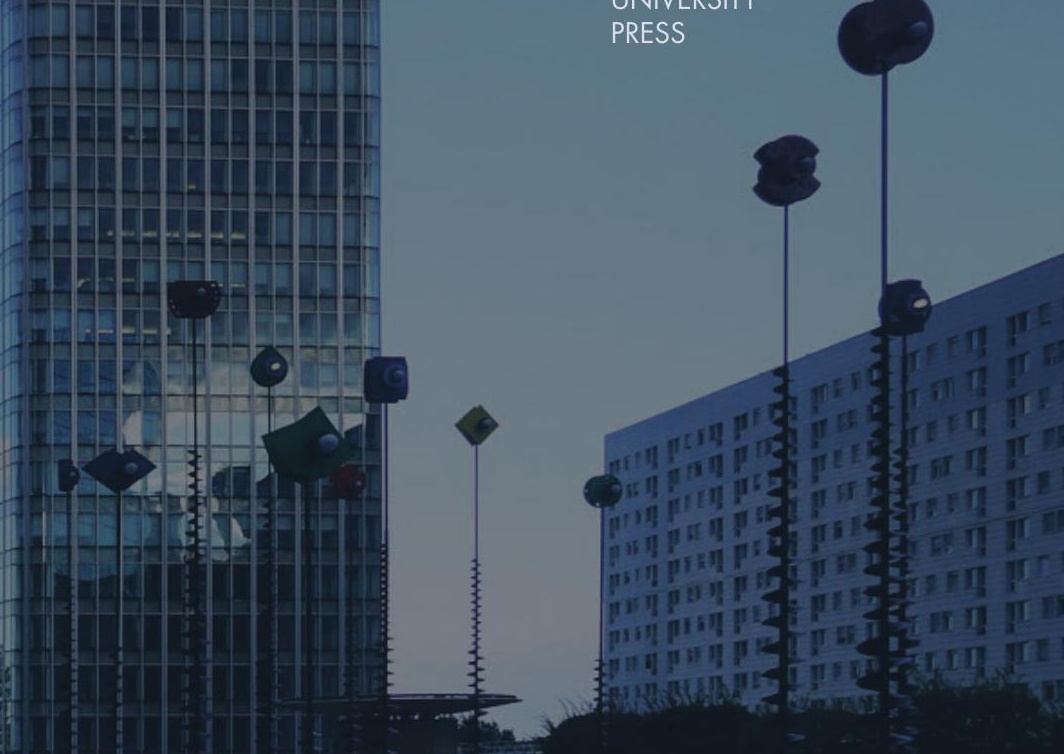

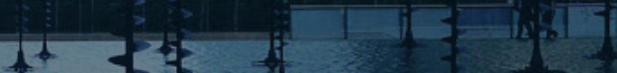

OS ESTADOS

EA ORDEM

INTERNACIONAL

CONTEMPORANEA

ATAS DO V ENCONTRO LUSO-ESPANHOL DE Professores de Direito internacional e RELAÇÕES INTERNACIONAIS 


\section{CINCO TÓPICOS SOBRE A CRISE POLÍTICA GLOBAL NUMA ERA DE COMPRESSÃO}

\section{Silvério da Rocha-Cunha}

1. Foi apenas com a emergência do Estado moderno que se afirmou o direito internacional. Com efeito, só na sequência do fim de uma visão unitária da ordem política europeia, fundada na dupla autoridade do Imperador e do Papa, com a ascensão da razão de estado, se pôde colocar com clareza o direito internacional ${ }^{1}$. Foi a partir desse momento que as relações entre os Estados passaram a legitimar uma nova perspetiva estratégica da política que tem vindo a prolongar-se até aos dias de hoje. Esta nova conceção do político vai conotar a soberania com o "macro-antropo" hobbesiano ${ }^{2}$, baseado num estado de natureza instrumental que transpõe para as unidades políticas o combate suposto entre indivíduos. E a transformação do velho ius publicum europaum, saído do paradigma de Vestefália, em um direito internacional ancorado no imaginário nacional mais não fez que reforçar essa mesma dimensão instrumental entre os Estados ${ }^{3}$. Por isso se explica a paradoxal continuidade deste paradigma por entre as imensas mutações e desenvolvimentos que entretanto se

${ }^{1}$ Cf. por todos, M. La Torre, Cittadinanza e Ordine Politico. Diritti, crisi dela sovranità e sfera pubblica: una prospettiva europea, Torino, Ed. Giappichelli, 2004, pp. 61 ss., que seguimos.

${ }^{2}$ Id., ibid., p. 63.

3 Id., ibid. 
verificaram ${ }^{4}$. Na verdade, sendo certo que o estatocentrismo tem vindo a ser posto em causa a partir dos processos transnacionais que se acumularam sobretudo nas últimas décadas, nem por isso deixaram de permanecer as principais marcas do projeto moderno na estrutura básica do sistema internacional.

A rutura moderna veio pôr cobro a um entendimento da política que pressupunha não só a Cidade como meio adequado de realização da natureza humana ${ }^{5}$, mas também concebia o seu objeto como o justo e virtuoso através da prudência, apontando, antes, para um entendimento da política como técnica de gestão de recursos escassos. A Pólis opunha-se necessariamente ao Oikos, já que a interação nascida no âmbito deste último espaço não passava de uma soma de vontades individuais destinada a regular e produzir meios de sobrevivência ${ }^{6}$. Não assim, porém, com o pensamento político moderno, de que Hobbes é um lídimo representante, que estabeleceu desde o início soluções de ordem técnica para a finalidade básica da autoconservação da vida dos homens, o que significa colocar como problema fundamental da afirmação da vida a relação de domínio, que passa a estar liberta de qualquer contexto ético. Hobbes procede a uma autêntica autonomização da soberania do príncipe mediante um contrato que exige o exercício do poder a fim de impedir a continuação de um estado de natureza mortífero para os homens. Como já foi observado, o novo complexo de interesses que se desenvolve no século XVII, nomeadamente a partir

\footnotetext{
${ }^{4}$ Cf., para uma síntese, R. Kolb, Réflexions de Philosophie du Droit International, Bruxelles, Ed. Bruylant/Ed. de l'Université de Bruxelles, 2003, pp. 5 ss.

5 Cf. J. Habermas, "La Doctrine Classique de la Politique dans ses Rapports avec la Philosophie Sociale", in Id., Théorie et Pratique, I, tr., Paris, Payot, 1975, pp. 71 ss., que seguimos. Para uma perspetiva global, cf. V. Marzocchi, Filosofia Politica, Roma-Bari, Laterza, 2011.

${ }^{6}$ Habermas, ibid., p. 76. Cf. ainda as reflexões de M. C. Fialho, "Do Oikos à Pólis de Agamémnon: sob o signo da distorção", Ágora. Estudos Clássicos em Debate, 14/2012, pp. 47 ss.
} 
da centralização do poder e da expansão da nascente economia capitalista no âmbito de um território "nacional”, determina um novo direito natural racional que assume a figura do contrato como sendo adequado por natureza à fundação da sociedade organizada ${ }^{7}$. Para uma paz e uma segurança efetivas nesta sociedade, contudo, os homens alienam a sua liberdade, confiando na compatibilização entre monopólio da violência legítima e gozo da liberdade de cada um. Mais: têm de acreditar que o controlo da violência se faz através da soberania de que só o soberano é titular e juiz. E é assim que, como demonstra Habermas, os conteúdos contratualistas sucumbem perante o absolutismo do Estado que os sanciona ${ }^{8}$.

Compreende-se, deste modo, que o direito internacional evidencie na sua genealogia vocação para direito de coexistência, apto para propiciar a sobrevivência e pouco mais. Todavia, a partir da segunda metade do século XX, um conjunto de ameaças e desafios impôs-se à consciência jurídica internacional, nomeadamente os perigos derivados do equilíbrio nuclear (a pax atomica ou pax timoris), bem como a crise ecológica, acabando por contribuir para um clima de compreensão da interdependência entre povos e Estados. É assim que se passa de um direito internacional de simples coexistência para um direito internacional que, mais do que de cooperação, pretende traduzir-se como um verdadeiro "direito da unidade do género humano" 9 , através de documentos tais como a Carta da ONU ou conceitos como o ius cogens, as obrigações erga omnes ou a

${ }^{7}$ Como diz Habermas, op. cit., p. 92, a dificuldade de Hobbes está em ter de "fazer derivar da causalidade regendo a natureza humana submetida aos seus instintos as normas de uma organização cuja função é precisamente a de coagir os homens a renunciar à satisfação primitiva dos seus instintos".

8 Id., ibid., p. 95. Por isso, pode dizer A. Passerin d'Entrèves, La Notion de l'Etat, tr., Paris, Sirey, 1967, p. 142-143, que "Unidade, unicidade, uniformidade: nenhum poder, nenhum direito, nenhuma sociedade, a não ser com o Estado e no interior do Estado", logo, o Estado de Hobbes é o Estado moderno, mas "é também, e ao mesmo tempo, a sua reductio ad absurdum, quase a sua caricatura".

9 Kolb, op. cit., p. 29. 
tipificação de crimes contra a humanidade, entre outros, tudo no sentido de reforçar polos que inspirem um "novo direito internacional dos homens ou de causas comuns"10.

Contudo, o facto de o direito internacional vigorar numa sociedade "geneticamente" precária, onde o equilíbrio entre valores comuns e interesses atomizados não conhece uma evolução muito clara, permite recuos e transformações que permitem facilmente o esboroamento, não apenas dos instrumentos que coordenam ações e mantêm a ordem, mas ainda - e sobretudo- das constelações dos valores políticos, jurídicos e culturais que os habitam ${ }^{11}$. Assim se compreende que os conflitos inerentes aos choques entre as esferas relativas aos direitos soberanistas dos Estados, aos direitos humanos e aos direitos dos povos, produzam incoerências e esbatimentos que provocam redistribuições do poder, crises de controlo, espaços não recíprocos e uma generalizada crise de legitimidade ${ }^{12}$.

2. Para compreender satisfatoriamente a complexidade do mundo caótico $^{13}$ que nos rodeia, é preciso assumir que a complexidade derivada dos fluxos e conexões que têm vindo a ser estabelecidos pela humanidade ao longo do tempo provoca, necessariamente, uma mescla paradoxal do novo com o velho, dificultando com isso a obtenção de grelhas e modelos de leitura razoavelmente explicativos da realidade. Apenas sabemos que essa mescla constitui, na verdade, uma regularidade de sempre. Nem por isso, contudo, o conhecimento desta "regularidade" permite uma visão satisfatória do presente. Com

${ }^{10}$ Id., ibid., p. 30

11 Cf. a importante obra de A. Colombo, La disunità del mondo. Dopo il secolo globale, Milano, Feltrinelli, 2010, que seguimos.

12 Cf., sobre toda esta problemática, R. Riquelme Cortado, Derecho internacional. Entre un orden global y fragmentado, Madrid, Ed. Biblioteca Nueva, 2005.

13 Cf. R. Menotti, Mondo Caos. Politica Internazionale e Nuovi Paradigmi Scientifici, Roma-Bari, Laterza, 2010. 
efeito, sabe-se que os seres humanos são, em última instância, os destinatários efetivos das relações internacionais, mas de facto surgem previamente "compactados" em unidades histórico-políticas que, de forma heterogénea, os distribuem pelo mundo, sem que cada um possa assumir o seu papel de sujeito nos processos políticos internacionais, e isto apesar da evolução tecnológica e das comunicações. Mesmo a explosão das trocas entre humanos e culturas, que nos parece de uma intensidade única e súbita, insere-se na realidade num processo de longa duração. É possível, assim, uma leitura no sentido de, como sublinha Menotti ${ }^{14}$, nos encontrarmos num momento de mudança de paradigma em virtude de uma exponencial densificação da complexidade. É possível que estejamos numa situação "hipercrítica", onde vêm à superfície as inevitáveis instabilidade e imprevisibilidade, que não apenas comprimem o tempo, mas ainda fazem desaparecer do próprio horizonte histórico quaisquer perspetivas de interpretação fundadas na complexidade, porquanto a compressão do tempo e do espaço elimina, aparentemente, a necessidade e o sentido da reflexão crítico-hermenêutica, para além da evidente densidade de problemas de algum modo novos que derivam de um planeta com problemas ecológicos e com uma população global que, nas suas particularidades históricas, se encontra confinada, pela primeira vez, num "sistema terrestre" fechado, logo aumentando drasticamente as probabilidades de conflitos de toda a natureza. Encontramo-nos, pois, num momento em que convicções ético-políticas, problemáticas organizativas, racionalidade instrumental, se opõem e anulam, se recortam, interagem, se misturam. Encontrar-nos-emos, então, perante uma ordem que, sob a figura de desordem, se vai restabelecendo, cosendo as fissuras que as conjunturas abrem momentaneamente, correspondendo a estádios da própria evolução humana? Ou, pelo contrário, somos vítimas de medos e transformações provocadas

14 Menotti, op. cit., p. 135. 
por uma Modernidade "enlouquecida"?15 É neste ponto de análise que necessitamos de ir mais além. Numa síntese precisa, já foram enumerados os tópicos que afetam o sistema internacional ${ }^{16}$ : o sentido da democracia, o papel da economia de mercado, o poder crescente do capital financeiro, as formas tradicionais do exercício do poder, o desenvolvimento económico, a tradicional política de poder, o advento de uma sociedade tecnológica cheia de promessas e limitações, em suma: "toda a cultura do século aparece dominada pela contraposição entre princípio (teoria) do relativo e dogmas ideologizados"17.

Daqui resulta uma apreciável dificuldade na determinação de um paradigma sólido para a interpretação da contemporaneidade. Tudo parece ter mudado e nada, aparentemente, mudou. Foi já dito, com notável audácia de estilo, que os sucessivos debates no âmbito da teoria internacional fazem lembrar o mítico acidente do Titanic: um navio sólido embate contra um icebergue e os seus passageiros menosprezam, numa primeira fase, a dimensão do acidente, tentando salvar-se, posteriormente, de forma algo atabalhoada. A "moral" da comparação aponta para a cegueira das construções absolutas, neste caso passageiros racionalistas que acabam por abandonar o navio sem saber como foi possível a catástrofe, e o icebergue representa as posturas reflexivistas ${ }^{18}$. Por entre os debates e as perplexidades em curso, importa sublinhar a relevância das posturas reflexivistas críticas, na medida em que permitem dar a devida dimensão às problemáticas interculturais

15 Cf., por todos, C. Baillargeon, Modernité et Liberté, Montréal, Ed. du Boréal, 2006

16 Cf. E. Di Nolfo, Dagli imperi militari agli imperi tecnologici, Roma-Bari, Laterza, 2007, pp. 412 ss.

17 Id. Ibid., p. 413.

18 Cf. por todos K. Sodupe, La Teoría de las Relaciones Internacionales a comienzos del Siglo XXI, Universidad del País Vasco, 2003, pp. 16-17; e D. Battistella, Théories des Relations Internationales, 3.ème éd., Paris, Sciences Po, 2009. 
que subjazem aos fenómenos globais, apontando a necessidade de abandonar as velhas, ainda que persistentes, posturas de natureza racionalista, que mais não fazem do que pretender "descrever" o mundo em termos empírico-analíticos, com isso dando continuidade às mais inadequadas e incompletas versões positivistas. Igualmente relevantes, porém, são as resistências à constatação de que permanece o poder, e não a política, o núcleo central da política internacional. Já foi notado como os sucessivos debates epistemológicos no âmbito das Relações Internacionais acabaram por perder a sua vertente mais "ontológica" e "incomensurável" para, em termos muito simples, se dedicarem a questões concretas, como os mecanismos de relação institucional, ou a cooperação dentro da anarquia, constituindo-se como corrente dominante a mescla entre as conceções do neorrealismo e do neoliberalismo, anteriormente portadoras de diferenças ${ }^{19}$. E isso é assim porque na política internacional estas perspetivas se unem num plano fundamental —o da consideração do poder como instância última de condução dos homens, permanecendo, nesse sentido, presas de construções globais apriorísticas, como, por exemplo, o de as relações entre os homens propenderem para uma dimensão trágica. E isto é assim mesmo sabendo-se que a soberania guerreira do Estado tem vindo a conhecer progressivamente reduções várias nos seus âmbitos de atuação, pois a proximidade planetária coloca a nu disjunções muito firmes relativamente à soberania, nos campos da organização da comunidade política, do direito, da segurança, da identidade e da economia ${ }^{20}$. A pujança da "sociedade-mundo" não pode deixar de opor à "economia-mundo" dominante uma alternativa paradigmática. Esta força está, porém, fortemente condicionada pela

19 Cf. K. Sodupe, op. cit., pp. 52 ss.

20 Cf. A. Mangiameli, Dans un Monde Post-National, Québec, Les Presses de l'Université Laval, 2009, pp. 21 ss. 
"feudalização" de muitas figuras que possuíam sentido e funções diferentes numa ordem jurídica que assentava na coexistência de Estados soberanos (é o exemplo da esfera pública, originariamente burguesa-liberal, que hoje não consegue representar-se numa sólida e una esfera pública mundial). Ora, só a consideração da política enquanto modo de expressão da pluralidade humana (para nos lembrarmos de uma expressão de Arendt) permite, na sua relativa indeterminação, as transições de que fala $W_{e n d t}{ }^{21}$ a propósito das "culturas" que permearam a humanidade desde sempre: a hobbesiana, assente no poder nu e cru, a lockeana, fundada no recurso limitado à força, e a kantiana, onde a anarquia surge como plena de potencialidades pacíficas e cooperativas, porquanto a qualidade da estrutura "anarquia" depende de procedimentos que, numa determinada conjuntura histórica, ou favorecem o poder e o interesse, ou a intersubjetividade entre humanos, e só esta confere sentido real ao mundo material das estruturas.

3. Mudança e permanência, eis duas ideias que parecem, nos tempos de hoje, de difícil articulação. $\mathrm{E}$ isto é assim porque a contemporaneidade olha a aceleração a que assistimos sob o prisma do progresso linear e, de forma paradoxal, com tendência a simplificar ainda mais a complexidade que sempre existiu, já que implica ação de curto prazo. E é esta uma das problemáticas que exige mais persistência na indagação: como agir hoje para garantir interesses na longa duração ${ }^{22}$. Encontramo-nos, deste modo, perante a problemática da natureza política do "tempo mundial", bem como da própria natureza da "compressão" a que está sujeita a civilização que de algum modo

21 Cf. A. Wendt, Teoria Sociale della Politica Internazionale, tr., Milano, Vita \& Pensiero, 2007, pp. 333 ss.

22 Cf. K. Sodupe, op. cit., p. 223. 
delimita as possibilidades desse mesmo tempo ${ }^{23}$. Pressupondo que o tempo mundial consagra, quer processos longos, quer matrizes de problemas e situações que de algum modo desaguam em ideias-valor dominantes que marcam uma época, Laïdi aponta ainda a necessidade de haver "ressonância" dessas ideias-valor e acontecimentos sobre outras estruturas simbólicas que garanta a generalização de que existe um "antes" e um "depois" daqueles. Assim, e como sustenta o Autor, existe uma rutura evidente entre o fim da Guerra Fria e a aceleração da globalização económico-financeira, podendo ela ser vista como a conexão que estabelece o atual tempo mundial, constituindo estes dois processos um conjunto que estabelece uma nova "problemática”. É evidente que esta ideia conduz à problemática de um tempo instantâneo que opera num espaço cada vez mais cheio e que, em consequência, agudiza contradições, conflitos, e torna a sensação de escassez mais absoluta, aumentando exponencialmente o medo. Como já explicou Hartmut Rosa, a vida dos homens que povoam as sociedades que determinam o tempo mundial é uma vida coordenada pelos "imperativos sistémicos" da sociedade capitalista, cujo "regime temporal rigoroso e estrito não é articulado em termos éticos", um "regime-tempo em grande parte invisível, despolitizado, indiscutível, subteorizado e inarticulado" 24 . Com efeito, a modernização, que trouxe consigo a racionalização das relações sociais, os processos de individualização e de diferenciação funcional, é igualmente legitimadora do produtivismo e da razão instrumental em termos que implicam necessariamente uma aceleração que se traduz, de facto, em compressão sociopolítica, pois na realidade o tempo não acele-

23 Sobre o tema cf. Z. Laïdi, "Le Temps Mondial" in M.-C. Smouts (dir.), Les Nouvelles Relations Internationales, Paris, Presses de Sciences Po, 1998, pp. 183 ss.; Z. Laïdi (org.), Le Temps Mondial, Bruxelles, Ed. Complexe, 1997; Z. Laïdi, A Chegada do Homem-Presente ou da Nova Condição do Tempo, tr., Lisboa, Piaget, 2001.

${ }^{24}$ Cf. H. Rosa, Aliénation et Accélération. Vers une Théorie critique de la modernité tardive, tr., Paris, La Découverte, 2012, p. 8, que seguimos. 
rou, acrescendo que na multiplicidade das atividades humanas há fenómenos de aceleração e outros de desaceleração ou manutenção. Segundo Rosa, as acelerações técnica, da mudança social e do ritmo de vida acabam por se traduzir no declínio da estabilidade institucional. Em simultâneo, a compressão é inevitável, porquanto, não obstante a técnica permitir respostas mais rápidas às tarefas que surgem como necessárias à manutenção do sistema social, o facto é que aumentou exponencialmente o número de tarefas a cumprir ${ }^{25}$. $\mathrm{E}$ isso é assim porque a competição individual e coletiva, incluindo a militar, tem vindo, em simultâneo, a provocar uma maior aceleração e a desestruturar todas as formas de gestão de recursos assentes na cooperação ou no reconhecimento de constelações de valores que assentem em pressupostos não mensuráveis em termos imediatos ${ }^{26}$.

Pode, por isso, falar-se de uma "cronopolítica" no sentido que lhe dá Innerarity ${ }^{27}$, isto é, no de saber quem impõe prazos e ritmos na evolução dos próprios processos sociais e políticos. O que a Modernidade ocidental possui de muito particular é pressupor a coexistência entre um tempo público fortemente dominado pelos aparatos de poder e um tempo individual que, aparentemente, cada indivíduo poderia gozar. De facto, porém, o tempo é acima de tudo o tempo do poder: "o poder equivale à capacidade de movimento" 28 . Tem razão, assim, Innerarity quando aponta a natureza profundamente política do tempo que surge precisamente como despolitizado, "neutro", e que rege a economia do subsistema financeiro, a comunicação social mundializada, na medida em que distribui recursos e estabelece relações assimétricas de poder,

25 Id., ibid., pp. 13-32.

${ }^{26}$ Id., ibid., passim.

27 Cf. D. Innerarity, Un Mundo Desincronizado, Bilbao, Universidad del País Vasco, 2008; e M. Delmas-Marty, Les Forces Imaginantes du Droit, II: Le Pluralisme Ordonné, Paris, Ed. du Seuil, 2006.

28 Innerarity, ibid., p. 4. 
mesmo que existam resistências e diferenciações entre indivíduos, grupos, e culturas ${ }^{29}$. O problema mais grave que se coloca ao mundo global é exatamente o da "heterocronia" que daqui deriva, pois se opõem não apenas disparidades no âmbito dos sistemas sociais, mas ainda uma disparidade mais profunda, se não mesmo abissal: a dessincronização entre, de um lado, os subsistemas das tecnologias e financeiro e, do outro, o subsistema da política, que implica não só eficiência, mas também debate e legitimação, entrando em rutura com o tempo rápido.

Estas dificuldades e contradições aumentam enormemente numa perspetiva mundial. Porque confrontando massas humanas em movimento num espaço já muito cerrado, pode falar-se numa agudização das relações de poder entre culturas e tempos diferentes, sobretudo num momento em que as elites políticas e financeiras dominantes pensam, eventualmente, a gestão política em termos de política de sobrevivência, em virtude da incerteza de um mundo onde surge como difícil sustentar desenhos de sociedade futuros dadas as ameaças e riscos que impendem sobre a humanidade ${ }^{30}$. Seria necessário, deste modo, um "tempo democrático", como sustenta Innerarity ${ }^{31}$. Ancorado na primazia da política, entendida esta enquanto "cimento" da coesão, da produção de legitimidade, este "tempo" sofre, como bem nota este Autor, múltiplas dificuldades, na medida em que se debate com a construção daquilo a que Delmas-Marty chama o desafio da "Grande Complexidade jurídica do mundo" 32 , que não poderá deixar de tentar ir por entre e para além de utopias de "Grande unidade" e de simples "pluralismos" em equilíbrios sempre tensos. E a realidade é que a construção de

\footnotetext{
29 Id., ibid.

30 Cf. M. Abélès, Politique de la Survie, Paris, Flammarion, 2006.

31 Cf. D. Innerarity, op. cit., pp. 12 ss.

32 Cf. M. Delmas-Marty, op. cit., p. 27.
} 
uma ordenação plural embate constantemente na propensão para os Estados tutelarem com maior rapidez a necessidade de articulação de natureza tecnoeconómica do que aquela que se reporta aos direitos humanos. Não que não existam momentos de velocidade conjunta, evidentemente, mas é facto que os Estados soberanos, bem como outros atores internacionais, tendem a uma aparentemente paradoxal disjunção. E, na verdade, compreende-se porquê: no primeiro caso encontramo-nos perante a prévia inserção do subsistema económico no âmbito da despolitização do mundo, típica do liberalismo, a que já aludem as polémicas teses de Carl Schmitt quando criticam sua sustentabilidade e sinteticamente definem o liberalismo assim: "Declamação ética e realismo materialista e económico"33. A perseguição de uma verdadeira "policronia", como deseja Mireille Delmas-Marty, adquire um sentido mais concreto com a ideia de "tempo democrático" em Innerarity, pois este assinala com muita clareza como a política democrática sofre a erosão provocada pelas pulsões tecno-numéricas que desequilibram profundamente as sociedades pluralistas, pois estas precisam não apenas de tempo para thes conferir sentido e as integrar na dinâmica da totalidade social, mas ainda de tempo democrático, que só se pode encontrar na dilação do debate discursivo. Mas este Autor tem razão quando assinala como se tornou o projeto moderno imensamente opaco num cenário mundial, porquanto a diferença entre passado e futuro, a compatibilidade entre tempo político-institucional com evolução social, por exemplo, se tornaram impossíveis de sustentar num mundo que tenta, a todo o custo, estilhaçar no presente o futuro que endeusa, afinal, de forma contraditória. Assim, como no-lo diz Innerarity, e não podemos deixar de subscrever a ideia acentuando a ironia, a esquerda pretende desacelerar porque defende as

33 Cf. C. Schmitt, La Notion de Politique * Théorie du Partisan, tr., Paris, Flammarion, 1992, p. 116. Num sentido otimista, cf. Delmas-Marty, op. cit. 
garantias do Estado de Direito e o princípio de legalidade original, enquanto o conservantismo fala da "genuinidade" do cesarismo político, de decisionismo antidemocrático, de circulação de bens sem constrangimentos, de gestão de recursos escassos em estado de emergência ${ }^{34}$, ainda que não dê fundamentos doutrinários para isso, sem se aperceber de que a compressão de que é apologista produz efeitos perversos relativamente aos ideais do iluminismo subjacente às revoluções liberais burguesas, nomeadamente o aniquilamento da esfera pública politizada à qual caberia o debate e a crítica dos assuntos públicos. Estas dificuldades são, quando elevadas ao nível planetário, praticamente insuperáveis, em virtude das diversidade e fragmentação, o que arrasta consigo a problemática da crise de legitimidade, pois é a própria memória do Ocidente que transmitiu, desde a "Oração Fúnebre" de Péricles, o "gene democrático" da virtude intrínseca da formação democrática da vontade política, logo, da estabilidade que permite compreender a arquitectónica do sistema social.

4. Os tempos de hoje são, por isso, tempos de uma "sociedade cercada”, para usar título feliz de Zygmunt Bauman ${ }^{35}$. Chamamos-lhe igualmente uma "sociedade de compressão". O que à partida implica diversas vertentes que podem de algum modo sintetizar-se num ponto: numa sociedade de incerteza quaisquer vínculos de pertença perdem força, o que nos coloca para além das estruturas e das instituições. Não será demais insistir: o mundo social da vida tem muito mais influência e complexidade do que aquilo que normalmente a teoria e as perspetivas sistémicas gostam de admitir. Como nota Bauman, todo o processo de conhecimento da "realidade" em que

${ }^{34}$ Cf. D. Innerarity, op. cit., pp. 12 ss., que seguimos.

35 Cf. Z. Bauman, La Société Assiégée, tr., Paris, Hachette, 2005. Cf. igualmente N. Lechner, Las Sombras del Mañana. La Dimensión subjectiva de la Política, Santiago de Chile, Ed. LOM, 2002. 
se empenhou a Modernidade pressupôs sempre uma "legitimidade" que, por nunca ter sido atingida, passou a constituir uma forma de poder "ideal" por realizar, mas teve como forma a sociedade do Estado-nação soberano. O que produziu como consequência a aparente "solução" de um paradoxo: o de o Estado moderno ser, a um tempo, parte e árbitro na história ${ }^{36}$. Quer o "Sistema de Estados Europeu", quer o "Sistema de Estados Civilizados", são manifestações paradigmáticas de uma Modernidade que se edificou em torno de um poder político organizado que se acoplou com essa comunidade de algum modo imaginária que foi e é a "Nação"37. Esta fusão que, segundo Bauman, dá razão às teses de um Foucault ou de um Agamben quando apontam para a verdadeira natureza "biopolítica" do poder moderno, na medida em que sempre coube a este último uma derradeira palavra sintetizado na expressão "Procurado: morto ou vivo"38 - explica a recorrente facilidade com que se recorre a ideias como as de "nacionalismo", "patriotismo" e similares, sem que para isso seja necessário recorrer a uma ideia clara de comunidade onde impere uma verdadeira vontade geral.

Mas, hoje, o quadro realmente mudou. Os sentimentos de pertença, mais ferozes que nunca (como é o caso dos terrorismos drásticos), continuam seduzidos pelo poder, mas este já não é um atributo exclusivo do Estado-nação de origem claramente eurocêntrica. Na verdade, a globalização não se limitou a empalidecer a soberania. Criou uma

\footnotetext{
36 Bauman, ibid., p. 12.

37 Cf., sobre esta problemática, B. Anderson, L'Imaginaire National, tr., Paris, La Découverte, 2002.

38 Bauman, op. cit., pp. 14-15. Daí este A. dar como correta a ideia de Agamben segundo a qual é esta ideia-base que justifica a capacidade quase extraordinária de nas sociedades ocidentais ter ocorrido um fenómeno como o totalitarismo. Sobre este tema, cf. a obra fundamental de G. Agamben, Homo Sacer. Le pouvoir souverain et la vie nue, tr., Paris, Ed. du Seuil, 1997; Id., Estado de Excepción (Homo Sacer II, 1), tr., Valencia, Pre-Textos, 2004. Sobre a problemática, que envolve Foucault e Carl Schmitt, cf. diversos textos in O. Feron (org.), A Modernidade entre Secularização e Teologia Politica (n. ${ }^{\circ}$ monográfico de Economia e Sociologia, Évora, 87/2009).
} 
nova etapa do "jogo do mundo" profundamente fluida e desregulada, onde não existem "totalidades independentes", como sublinha de novo Bauman. Assim, enquanto nos últimos dois séculos a dinâmica social se desenvolveu no marco do Estado-nação, constituindo-se uma "sociedade de produtores" e de indivíduos com identidade "estável"39, a atualidade é caracterizada por uma sociedade da informação que é desprovida das características da esfera pública liberal ${ }^{40}$, porquanto é fundada numa "telecracia" genérica que não só diluiu a identidade "nacional", mas também criou uma atomização dos indivíduos que impede a consciencialização da sua cidadania. Innerarity ${ }^{41}$ diz que a sociedade atual criou uma imagem "heterárquica", uma sociedade "multicontextual" onde a ordem é inevitavelmente policêntrica, onde a contingência se tornou uma plataforma permanente onde não é possível efetuar observações "racionais" 42 .

O problema desta sociedade é o de saber se corresponde a uma verdadeira ultrapassagem do projeto moderno, se corresponde a uma etapa da sua incompletude ou, mesmo, se é uma revivescência dos seus impasses ${ }^{43}$. Com efeito, o discurso moderno, pretendendo sê-lo para a "Humanidade", não só foi de facto restrito, mas também provocou o aparecimento de imensos anticorpos que alteraram o "desenho" inicialmente previsto. Só assim se compreendem fenómenos como a exclusão do Outro mediante o estabelecimento de

39 Cf. N. Bilbeny, Democracia para la Diversidad, Barcelona, Ariel, 1999, pp. 59 ss.

40 Cf. por todos D. Innerarity, El Nuevo Espacio Público, Madrid, Espasa Calpe, 2006.

41 Id., ibid., pp. 128-131

42 Como bem diz Innerarity, "em nenhuma configuração da sociedade houve mais saber acerca do não-saber, mais ignorância instruída, e em nenhuma foi mais problemático obter observações (...) sobre a sua própria racionalidade sem estimular ao mesmo tempo possibilidades laterais de observação que também poderiam caracterizar-se como racionais" (Id., ibid., p. 131).

43 Cf. a reflexão, em diálogo com K.-O. Apel, de J. A. Pérez Tapias, "Mas allá de la Facticidad, más acá de la Idealidad", in D. Blanco Fernández, J. A. Pérez Tapias \& L. Sáez Rueda (eds.), Discurso y Realidad. En debate con K.-O. Apel, Madrid, Trotta, 1994, pp. 207 ss. 
fronteiras fundadoras de imaginários não universais, onde deixaram de contar para o sistema social categorias que vão desde os povos "bárbaros" até excluídos dentro do próprio sistema (como, por exemplo, as mulheres e as classes trabalhadoras). O próprio conceito de Estado soberano transportou consigo a categoria do "Uno", armadilhando e amarrando os direitos e a cidadania às suas fronteiras político-jurídicas, por um lado, e propiciando, por outro, o exercício da "microfísica do Poder", ou seja, de estruturas de domínio dos indivíduos dentro de um sistema social cujo discurso ideológico não deixou nunca, porém, de propalar a liberdade individual irrestrita ${ }^{44}$. Estas restrições, que se verificaram interna e externamente, não aconteceram porque a nova sociedade estivesse apostada na "realização" da verdade, nem porque o seu relativismo de princípio fosse determinado por um ideal de Razão, mas, antes, porque se tornou necessário manter um determinado padrão de "ordem".

5. Pode, assim, dizer-se que um dos paradoxos da modernidade é nunca ter atingido as finalidades que se propôs, embora tenha inundado o espaço histórico com um discurso que pretendeu superar todas as contradições inerentes às suas limitações. E estas limitações traduzem-se numa enorme ambivalência: de um lado, uma modernidade incompleta, em nome de um liberalismo puro; do outro, uma modernidade transformada por uma organização político-social cada vez mais complexa, com um progressivo intervencionismo do poder estatal, em nome de um liberalismo cada vez mais intangível. Um dos melhores expoentes destes dilemas é o pensamento de Max Weber, por exemplo, que examina a não

${ }^{44}$ Impõe-se aqui referir as teses de Michel Foucault, amplamente expostas nos seus cursos no Collège de France "Il faut défendre la Société" (1976), Sécurité, Territoire, Population (1977-78) e Naissance de la Biopolitique (1978-79), todos editados por Gallimard/Seuil. 
superação das contradições da "jaula de ferro" em que tombou a racionalidade ocidental ${ }^{45}$, e cuja conclusão podemos aqui resumir da seguinte forma: a emancipação da razão, que permitiu ao homem encarar com êxito o domínio material da natureza, que deveria propiciar meios para esse mesmo homem se dedicar sem peias ao exercício da liberdade, acabou por se transformar numa finalidade da existência social, logo, num mecanismo de opressão dos indivíduos. Neste sentido, e como bem observa Peter Wagner, existe uma semelhança estrutural entre a organização da Modernidade ocidental capitalista na sua versão organizativa e a organização da Modernidade na sua versão extrema do socialismo coletivista, cujo modelo histórico real foi essencialmente abalado a partir de 1989, na medida em que ambas são respostas à Modernidade restrita que realmente emergiu com as revoluções modernas ${ }^{46}$. É óbvio que, num plano mais macroscópico, esta similitude é total, porquanto ambos os modelos pertencem a esse movimento mais profundo que, como acima foi dito, determina de modo ambivalente o homem moderno: buscando a certeza pelo domínio crescente da natureza, o homem sente-se cada vez mais incerto, atirado que está "num espaço-tempo onde sopra um vento frio" 47 , para o qual os modelos de ordem e as teorias que a estruturam acabam sempre por não ser solução. A errância que preexiste ao humano, e de que ele foge incessantemente, é sistematicamente ignorada pela civilização técnica em que a Modernidade mergulhou com decisão, deixando que a técnica "mito-tecnologicamente, desdivinize, desnaturalize, desumanize, desindividualize, dessocialize" 48 ,

45 Cf. P. Bouretz, Les Promesses du Monde. Philosophie de Max Weber, Paris, Gallimard, 1996, pp. 366 ss.

46 Cf. P. Wagner, Liberté et Discipline. Les deux crises de la Modernité, tr., Paris, Métailié, 1996, pp. 164 ss.

47 K. Axelos, Ce Questionnement, Paris, Ed. de Minuit, 2001, p. 27.

48 Id., ibid., p. 34. 
pensando dentro do círculo que julga romper ${ }^{49}$, limitando-se a articular antagonismos complementares.

Compreende-se, assim, o aparecimento da conhecida "crise de legitimidade" 50 que assola as sociedades desenvolvidas desde a década de 70, fundamentalmente derivadas da contradição entre um "conglomerado herdado", que não pode ser apagado em qualquer caso, e aspirações de mudança entre si igualmente contraditórias, a que os sistemas jurídicos foram dando cobertura, nomeadamente a contestação de práticas sociais estabelecidas e a reinvenção de um novo sujeito histórico ${ }^{51}$. Seja como for, o momento atual continua a ser de uma opacidade que, por isso mesmo, não se encontra em condições de compreender, nem os efeitos de homogeneização da globalização, nem a capacidade de indivíduos e comunidades se individualizarem e escaparem aos constrangimentos sistémicos. É verdade que esta dificuldade tem muito a ver com a ilimitada crença no progresso tecnocientífico de que já falámos neste estudo, que dominou e determinou aquilo a que já se pôde chamar as três principais lógicas da Modernidade: a divisão funcional do trabalho, a arte de governar e a tecnologia. E é igualmente certo que esta confiança cega tem impedido a capacidade de uma autorreflexão crítica para apresentar alternativas, embora tenha permitido uma dinâmica que tem parecido imparável.

${ }^{49}$ Exprimindo bem este impasse, Axelos, ibid., p. 83, interroga-se: "Que sucede quando uma sociedade inteira, que se globaliza, vacila, se torna incerta, quando nenhuma perspetiva de transformação radical se desenha? A pobreza continua e aumenta, assim como o vazio da alma e a ausência de pensamento. Como uma economia mercantil dita mundial pode prosseguir o seu caminho, sem maiores conflitos, apenas efetuando reformas parciais e perpétuas?” Deste mesmo A. cf. uma reflexão sobre a erosão existente no âmbito da União Europeia: K. Axelos, "Qual poderá ser o advir da Europa futura?", in AA.VV., Conferências de Filosofia da Faculdade de Letras da Universidade do Porto, Porto, Campo das Letras, 2000, pp. 19 ss.

50 Cf. por todos J. Habermas, Raison et Légitimité. Problèmes de Légitimation dans le Capitalisme Avancé, tr., Paris, Payot, 1978; C. Offe, Lo Stato nel Capitalismo Maturo, tr., Milano, Etas, 1977; A. Porras Nadales [ed.], El debate sobre la crisis de la representación política, Madrid, Tecnos, 1996.

51 Cf. P. Wagner, op. cit., pp. 219 ss. 
E, de facto, assim tem sido à medida que o pragmatismo e o procedimentalismo políticos se confundem com os princípios que deveriam enformá-los. O que se traduz na possibilidade de um efeito uniformizador que, de facto, no atual contexto global policêntrico a todos os níveis, ajuda à promoção de um agudo individualismo e não do universalismo, porquanto o que surge como evidente é uma visão difusa de "comunicação global" que testemunha a interdependência em que vivemos em termos tecnoeconómicos, sim, mas não implica "a ecumenização das autoridades políticas, culturais e morais" ${ }^{2}$, pois o que está em jogo é uma racionalidade estratégica de apropriação de espaços, tempos e $\operatorname{mercados}^{53}$, cujo fundamento se pode encontrar no pensamento sistémico de um Luhmann quando este olha os sistemas sociais como "imperativos independentes", ou seja, dotados de uma natureza autorreguladora, autopoiética e autorreferencial, como diz Michel Freitag, operando como "processos sem sujeito nem fim" 54 , onde o conflito não é um problema de comunicação, mas uma forma quase "neutra" de comunicação, e esquecendo que, na realidade, qualquer autorregulação pressupõe, inevitavelmente, um momento de unidade que não pode ser o sistema. E este momento de unidade é, na sociedade moderna, aquele em se fixam constelações de valores que são em si mesmos contraditórios, mas que se unem pela mensagem que transmitem à Humanidade sem mais, cristalizando utopias, que o liberalismo também assumiu na sua fase inicial, na sua fase revolucionária, que se sustentou nesse "excedente" que instituiu um imaginário político que persistiu e de algum modo permanece em muitas versões do

52 Z. Bauman, Ética Pós-moderna, tr., São Paulo, Paulus, 1997, p. 53.

53 Cf. por todos M. Freitag, L'Abîme de la Liberté. Critique du Libéralisme, Montréal, Liber, 2011, pp. 259 ss., que seguimos.

${ }^{54}$ Luhmann apud M. Freitag, ibid., p. 276. Para uma perspetiva sobre o Autor, cf. H. Rabault, Un Monde sans Réalité? En compagnie de Niklas Lubmann: épistémologie, politique et droit, Québec, Presses de l'Université Laval, 2012. 
liberalismo contemporâneo ${ }^{55}$. A versão autorreferencial do liberalismo económico, que inclusivamente se emancipa progressivamente da natureza social das trocas, elimina o lado normativo que preside à formação dos vínculos sociais. Ao lado da ação social surge com força notável a operação sistémica de tipo comportamental ${ }^{56}$, que irá enlaçar-se de forma coerente com a ideia de uma aceleração contínua de um progresso técnico em si mesmo visto como linear.

Este efeito uniformizador é forçosamente simplificador, na medida em que, por um lado, já parte dos pressupostos em boa medida solipsistas da Modernidade - que circunscrevem a ação humana a interesses estratégicos bem delimitados e organizados que garantem segurança- e, por outro, é vivido de forma tão rápida, global e $\operatorname{arriscada}^{57}$ que destrói as velhas garantias do liberalismo burguês e as medidas do Estado Social de Direito. Deste modo passou a ser dominante uma leitura minimalista da Ordem, que no fundo corresponde a uma aparentemente paradoxal "regionalização" do Estado, pois este continuou a exercer as suas funções de detentor do monopólio da coação física legítima ao mesmo tempo que recuou na sua capacidade discursiva de, em teoria, impor limites materiais e ético-políticos ao mercado e, em virtude da natureza deste, ao seu sempre latente fundamentalismo ${ }^{58}$. Daqui decorre uma questão que já tem sido equacionada noutros termos, mas igualmente importantes para o nosso inventário crítico, e a que já aludimos. Com efeito, parece ser pressuposto de algumas das versões mais importantes do liberalismo

55 Cf. por todos E. Bloch, Droit Naturel et Dignité Humaine, tr., Paris, Payot, 1976.

56 Cf. M. Freitag, op. cit., p. 278. Acrescenta o Autor que talvez seja a partir daqui que emerge uma realidade crematística claramente oposta à clássica oikonomia.

57 Será caso para aludir ao conceito de Ulrich Beck da "sociedade do risco". Da sua vasta obra cf. Beck, La Sociedad del Riesgo Global, tr., 2. ${ }^{a}$ ed., Madrid, Siglo XXI, 2006.

58 Cf. P. Lanceros, "All that is solid. Política(s) de la Globalización", in A. OrtizOsés \& P. Lanceros [eds.], La Interpretación del Mundo. Cuestiones para el Tercer Milenio, Barcelona-México, Editorial Anthropos/Universidad Autónoma MetropolitanaIztapalapa, 2006, pp. 11 ss. 
o de que o ideal será a criação de uma sociedade de algum modo "pós-política"59, o que poderá constituir um "défice explicativo" do próprio liberalismo, como sustenta Panebianco, pois o pressuposto de que é possível uma despolitização de grande parte da vida social, nomeadamente a esfera económica, é pressupor igualmente que a distribuição de recursos não se funda numa qualquer espécie de "ordem", que os recursos não são suficientemente escassos para obrigar o uso da violência institucionalizada. Com efeito, o liberalismo é, sob um certo ponto de vista, uma imensa perplexidade entre, de um lado, uma ideia de política compatível com a liberdade natural de cada indivíduo e, do outro, uma visão da política como ameaça real à liberdade 60 . Em certo sentido, a explicação de Panebianco para esta contradição é plausível -a liberdade tem de possuir o suporte da segurança, o que implica pressões contraditórias sobre a política e o poder-, mas em todo o caso trata-se de uma visão que, de facto, nunca se conseguiu cristalizar em termos históricos, seja no plano dos fins últimos, seja no âmbito político-institucional. O que tem sucedido na evolução do Ocidente é uma enorme e não resolvida tensão entre medo/proteção/ordem política e necessidade de liberdade/rebelião/ desordem ${ }^{61}$. Ora, a partir do momento em que esta tensão se resolve efetivamente através do uso do poder a que corresponde uma deliberada ocultação da natureza política do subsistema económico, abrindo-o por completo à racionalidade utilitarista de recorte instrumental nas relações entre unidades políticas, perde-se inteiramente a possibilidade de referência a valores substantivos definidos pelo próprio liberalismo, a começar pela liberdade, passando a vigorar limitadamente e de forma intermitente,

\footnotetext{
59 Cf. por todos A. Panebianco, Il Potere, lo Stato, la Libertà, Bologna, 2004, que seguimos neste ponto.

${ }^{60}$ Id., ibid.

61 Id., ibid., pp. 34-35.
} 
o que conduz a uma realidade social proteiforme e débil quanto ao reconhecimento dos seus fundamentos, desprovida de consistência ontológica própria ${ }^{62}$. Não surpreende, pois, que haja uma particular incidência da realidade do poder em geral e, em particular, no sistema internacional, incluindo nas relações entre unidades políticas historicamente tidas como estáveis e democráticas, por isso se falando de "anarquia madura", logo, de probabilidade mínima de conflito entre regimes democráticos. Todavia, o facto é que, sendo verdadeira a constatação de que o próprio processo de globalização atual depende desta capacidade de os Estados se entenderem entre si em virtude do "gene democrático" que neles habita, gene que tem sido cultivado no âmbito de um clima liberal, nem por isso desapareceu a sombra do poder enquanto tal, porquanto as desigualdades reais entre unidades políticas existe como sempre existiu, a hegemonia "benigna" de uma delas continua a ser garante do sistema, a ameaça de guerra permanece endémica ${ }^{63}$. Assim, a liberdade de algum modo prometida permanece irresoluta e, em consequência, frágil. Na verdade, as sociedades da era de compressão perderam a política enquanto instância básica de autoconstituição do seu imaginário instituinte, passando a integrar-se no âmbito de um "sistema operacional" indiferenciado, que determina e compacta os indivíduos em função de fluxos financeiros que orientam o consumo estandardizado e fixam a grande massa de humanos em "não-lugares", para lembrar o título famoso de Marc Augé, ou seja, em lugares desprovidos de diferença, história e memória ${ }^{64}$. Podemos dizer, em suma, que o liberalismo dominante, prenhe de contradições, transformou a sua utopia progressista numa concreta multidão histórica de sítios distópicos.

\footnotetext{
62 V« Cf. M. Freitag, op. cit., p. 299.

63 Cf. A. Panebianco, op. cit., pp. 287 ss.

64 Cf. M. Freitag, op. cit., pp. 435 ss.
} 